\title{
The Impact of Foreign Banks on Monetary Policy Transmission during the Global Financial Crisis of 2008-2009: Evidence from Korea
}

\author{
Bang Nam Jeon* \\ Hosung Lim** \\ Ji $\mathbf{W u}^{* * *}$
}

The views expressed herein are those of the authors and do not necessarily reflect the official views of the Bank of Korea. When reporting or citing this paper, the authors' names should always be explicitly stated.

* School of Economics, Bennett S. LeBow College of Business, Drexel University, Philadelphia, PA 19104, USA, E-mail: jeonbana@gmail.com

** Economic Research Institute, The Bank of Korea, Seoul, Korea, E-mail: hosung@bok.or.kr

*** Department of Economics, Pennsylvania State University-Harrisburg, PA 17057, USA, and Research Institute of Economics and Management, Southwestern University of Finance and Economics, Chengdu, China, E-mail: juw25@psu.edu

This paper was prepared as one of joint research projects between the Bank of Korea (BOK) and the Korea-America Economic Association (KAEA). We appreciate Woon Gyu Choi, Hyun Jeong Kim, Kyuil Chung, Junhan Kim, Hyung-Kwon Jeong, Byung Kwun Ahn, Yo Chul Choi and session participants for very useful comments and suggestions, which were provided at the research seminar held at the Bank of Korea, July 2013. 


\section{Contents}

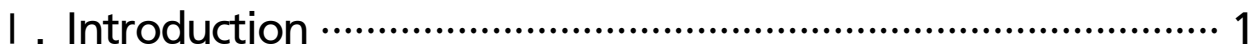

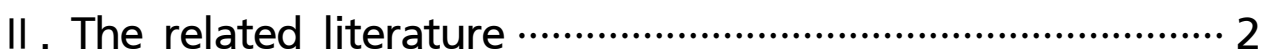

III. Model, data and estimation methodology ……………….... 4

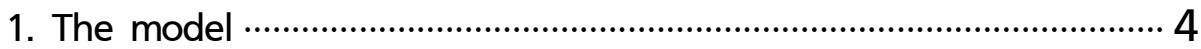

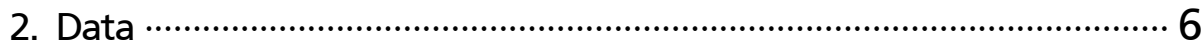

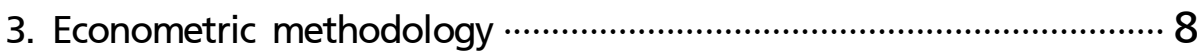

IV . Estimation results ……........................................................ 8

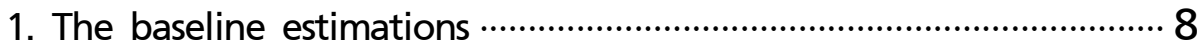

2. Foreign bank branches: US bank branches vs. non-US bank branches … 11

3. Global vs. regional foreign bank branches ……............................. 13

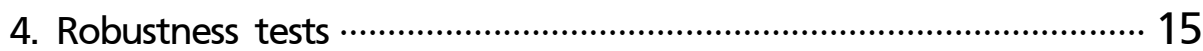

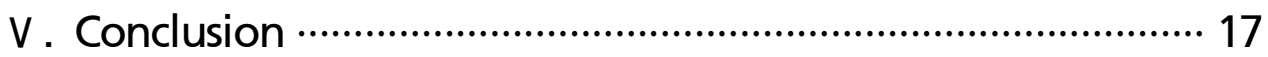

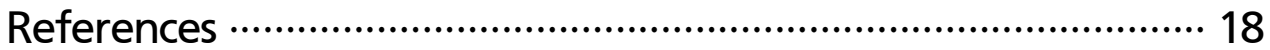

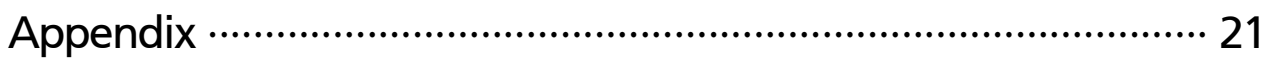




\section{The Impact of Foreign Banks on Monetary Policy Transmission during the Global Financial Crisis of 2008-2009: Evidence from Korea}

This paper examines the impact of foreign banks on the monetary policy transmission mechanism in the Korean economy during the period from 2000 to 2012, with a specific focus on the lending behavior by banks with different types of ownership. Using the bank-level panel data of the banking system in Korea, we present consistent evidence on the buffering impact of foreign banks, especially foreign bank branches including American bank branches, on the effectiveness of the monetary policy transmission mechanism in Korea from the bank-lending channel perspective during the period of the global financial crisis of 2008-2009.

Findings of this paper suggest that foreign bank branches reduced their lending when the Bank of Korea lowered its base rate substantially to conduct expansionary monetary policy during the global financial crisis period. One of the underlying reasons for this buffering effect by foreign bank branches is the existence of internal capital markets operated by multinational banks to overcome capital market frictions faced when the foreign banks finance their loans.

Keywords: foreign banks, monetary policy transmission, financial crisis

JEL Classification: G21, E52, G01 


\section{Introduction}

This paper examines the impact of foreign banks on the monetary policy transmission mechanism in the Korean economy during the period from 2000 to 2012, with a specific focus on the global financial crisis of 2008-2009. We specifically focus on the bank lending channel as the monetary policy transmission mechanism in Korea. We also investigate how different types and country-origin of foreign banks affect the effectiveness of monetary policy transmission in Korea in the midst of the increasing presence of foreign banks in the Korean banking market.

The recent global financial crisis of 2008-2009 provides a case for the first significant test for evaluating the stabilizing/destabilizing role of foreign banks in an emerging Asian economy, Korea, after experiencing a steady increase in foreign ownership in its banking sector. During the recent global financial crisis, it has been observed that many local subsidiaries of foreign banks in Asia reduced their credit by a larger extent than their domestic counterparts. The accurate assessment of the impact of the increased foreign bank penetration into host emerging Asian economies has been an important issue and has been called for by academicians as well as policymakers. This paper examines these issues for the case of Korea.

Using the data in the Korean banking sector provides unique opportunities for us to investigate the role of foreign banks in monetary policy transmission in an environment where the presence of foreign banks has increased steadily since the 1997 Asian financial crisis, and banks play an important role in transmitting monetary policy to the Korean economy and facilitating project financing and economic growth. In contrast to emerging Asia, the banking sector in Eastern Europe is too dominated by foreign banks over the weak presence of domestic banks, and in Latin America foreign banks have not been affected significantly, compared to other regions, by the recent global financial crisis. ${ }^{1)}$

The main contribution of this paper includes the provision of consistent evidence on the buffering impact of foreign banks on the effectiveness of the monetary policy transmission mechanism from the bank-lending channel perspective in an

1) For the differences in the bank ownership structure between banks in the Asia-Pacific region and those in other regions including North America, Europe, Latin America and Africa, see Hossain et al. (2013). 
emerging Asian economy, Korea, during the period of global financial crisis of 2008-2009. We expect that the main findings of this paper will have useful policy implications for monetary authorities and bank regulators to minimize the adverse effects of the increasing presence of foreign banks on the stability and effectiveness of monetary policy in the Korean economy.

The remainder of this paper is organized as follows. Section 2 reviews the related literature on the role of foreign banks in emerging economies. Section 3 describes the model, data and methodology used in the study. Section 4 reports and discusses the empirical results, followed by robustness checks in section 5 . Section 6 concludes.

\section{The related literature}

Various concerns on the role of foreign banks in host countries have been raised and discussed in the literature. For example, foreign banks lack hard information on the credit worthiness of smaller-size borrowers in local markets, tend to have higher interest margins and profitability than domestic banks in developing countries, and lead domestic banking markets to lower competition. Other additional concerns posited in recent years include a sudden stop or reversal of capital and credits during difficult times, especially when the parent banks in home countries suffer from the credit crunch or capital loss. The researchers have presented evidence that foreign banks are a major channel of the financial shock transmission or contagion, and pose a significant challenge to the effectiveness of monetary policy in host economies (see, for example, Cetorelli and Goldberg (2012a, 2012b) and Jeon et al. (2013)).2)

Regarding the role of foreign banks in host countries' monetary policy transmission mechanism, extant literature reports only scarce (and even mixed) empirical evidence on the impact of foreign banks on the effectiveness of the monetary policy transmission in host economies. Wu et al. (2011) find evidence that foreign banks, compared to domestic counterparts, are less sensitive to changes in the host

2) For a counter-example, see Jain-Chandra et al. (2013). 
monetary policy in adjusting their loans and interest rate, even after controlling for the heterogeneity in liquidity, capitalization, size and cost efficiency at the individual bank level. Arena et al. (2007) also find difference between domestic and foreign banks in the loan growth rate and the lending interest rate in response to changes in monetary policy, but only as significant among lower liquid and capitalized banks. In addition, the research on the impact of foreign bank presence on the monetary policy transmission concentrates on Central and Eastern Europe and Latin America, but is still scanty for emerging Asian economies.

A few recent papers have ascribed the insensitivity of foreign bank subsidiaries to host country monetary policies, relative to domestic banks, to their parent banks' global-wide liquidity and assets management. This is especially so when the global banks are hit by various forms of financial stress. For example, the intra-group capital flows from U.S. banks' affiliates abroad to their head offices increased (or flows from head offices to their foreign affiliates decreased) when the liquidity condition is tightened in the U.S., as shown by Cetorelli and Goldberg (2010, 2012a, 2012b).

It was also reported that in 2008 and 2009, the U.S. branches of foreign banks used the Fed discount window actively to raise funds and channeled them back to their parent banks, thus alleviating the degree to which parent banks had to be engaged in "fire-sale" of assets to meet their liquidity demand. As a matter of fact, these reversed capital flows (from subsidiaries to parents) were not rare at the time of home crisis when head offices' uncertainty regarding their ability to meet capital requirement and maintain liquidity increased substantially.

Our paper aims to fill the gap in the literature by using bank-level panel data and investigating the impact of increased foreign bank penetration on the monetary policy transmission mechanism in an emerging Asian economy, Korea, during the period from 2000 to 2012. We put a specific focus on loan growth by foreign banks (subsidiaries and branches), compared to domestic banks, during the recent global financial crisis. 


\section{Model, data and estimation methodology}

\section{The model}

Our empirical model examines the major determinants of loan growth by banks with different types of ownership. Our model is similar to the models used by Kashyap and Stein (1995), Kishan and Opiela (2000) and Gambacorta (2005):

$$
\begin{aligned}
y_{i, t}= & c+\sum_{j=1}^{4} \alpha_{j} y_{i, t-j}+\sum_{j=0}^{4} \beta_{j} M P_{t-j}+\sum_{q=1}^{5} \chi_{q} \text { char }_{q, i, t-1}+\sum_{q=1}^{5} \sum_{j=0}^{4} \Phi_{q j} \text { char }_{q, i, t-1} M P_{t-j} \\
& +\sum_{n=1}^{2} \delta_{n} \text { foreign }_{n, i, t}+\psi \text { crisis }_{t}+\sum_{n=1}^{2} \gamma_{n} \text { foreign }_{n, i, t} \text { crisis }_{t}+\sum_{j=0}^{4} \kappa_{j} \text { crisis }_{t} M P_{t-j} \\
& +\sum_{n=1}^{2} \sum_{j=0}^{4} \eta_{n j} \text { foreign }_{n, i, t} M P_{t-j}+\sum_{n=1}^{2} \sum_{j=0}^{4} \theta_{n j} \text { foreign }_{n, i, t} \text { crisis }_{t} M P_{t-j} \\
& +\sum_{q=1}^{5} \sum_{j=0}^{4} \rho_{q j} \text { char }_{q, i, t-1} \text { crisis }_{t} M P_{t-j}+\sum_{n=1}^{2} \sum_{j=0}^{4} \sigma_{n j} \text { macro }_{n, t-j}+\text { dummies }+f_{i}+\epsilon_{i t}
\end{aligned}
$$

with $i=1, \ldots, N$ and $t=1, \ldots, T$ and where the dependent variable $y_{i t}$ is the growth rate of net loans (in real term), calculated as the first order difference of the log of the loans of bank $i$ in quarter $t$. MP represents the monetary policy shock (described below). foreign is a vector of two dummies to represent the different types of foreign ownership of international banks, respectively subsidiary and branch. crisis is the dummy for the recent global financial crisis. char is a vector of bank individual characteristics, including liquidity, capitalization, size, riskiness, and profitability. macro is a vector of two macroeconomic variables, the growth rate of real GDP and the change in the unemployment rate. Other dummies include the seasonal and annual dummies and $f_{i}$ is the bank-specific fixed effect.

The growth rate of loans, adjusted by using GDP deflator, is regressed on 4 lags of itself, as a standard practice in extant literature. $M P$ is the first order difference of BOK's base rate relative to last quarter, hence a positive (negative) $M P$ suggests a contractionary (expansionary) monetary adjustment by the Korean monetary authority, and a zero in MP suggests the central bank maintains the monetary supply against 
last quarter. The sum of the coefficients, $\beta_{j}$, which indicates the cumulative response of bank loans to monetary policy shock, is expected to be negative. Given the lags of the dependent variable, the long-run elasticity of bank loans to monetary policy shock is calculated as: $\sum_{j=0}^{4} \beta_{j} /\left(1-\sum_{j=1}^{4} \alpha_{j}\right)$.

The dummy, crisis, is equal to 1 for the period 2008Q3-2009Q4. crisis is interacted with $M P$ to distinguish the effects of monetary policy in tranquil periods and the recent global financial turmoil. In order to detect the heterogeneous response of domestic and foreign banks, MP is interacted with the dummy subsidiary and branch, which is respectively equal to 1 for subsidiary and branch. The coefficient, $\eta$, suggests foreign banks' different monetary policy responses in non-crisis periods. The 3-way interaction terms, foreign $\times$ crisis $\times M P$, detects foreign banks' (different) sensitivity to Korean monetary policy shock in 2008-2009 global financial crisis. If foreign banks are less responsive to host monetary shock, the cumulative sum of $\theta$ will be positive.

The vector of bank characteristics, char, includes liquidity, capitalization, size, riskiness and profitability. Liquidity is measured by using the ratio of cash and due from other banks to total assets. We exclude securities from the composition of bank's liquid assets because the data on securities are only available after 2004 . Capitalization is proxied by the ratio of equity to total assets. Size is defined as the log of bank's total assets. Riskiness is measured by bank's net charge-off over net loans, and profitability is proxied by return on equity. In order to avoid the problem of endogeneity, we use one quarter lag of the bank characteristic variables.

The above five bank characteristics are all normalized with respect to the mean across all banks, in order to get indicators that sum to zero over all observations. Following the literature on bank lending channel, banks with heterogeneous characteristics have different ability to be shielded from the impact of monetary shock, so we interact char with MP. Since all char have been normalized, the average of the 2-way interaction terms (namely liquidity $\times M P$, capitalization $\times M P$, size $\times M P$, riskiness $\times$ $M P$ and profitability $\times M P$ ) are also equal to zero, hence the coefficient $\beta$ can be directly interpreted as the effect of monetary policy shocks on the average bank.

The variables in char are also 3-way interacted with $M P$ and the dummy crisis to detect how heterogeneous banks react to MPdifferently in the recent global financial 
crisis. If we observe foreign banks having different degrees of the sensitivity to host monetary policy in crisis, we can safely conclude it is not driven by banks' heterogeneous characteristics but the foreign ownership of the banks.

Two macroeconomic variables, the growth rate of real GDP and the change in the unemployment rate, are included in the regression to control for the demand effect on bank lending.

\section{Data}

We construct an unbalanced panel dataset using both bank-level data and macroeconomic data. We obtain the bank-level data set on balance sheet data from commercial banks in Korea (domestic banks and branches and subsidiaries of foreign banks doing business in Korea, for the period 2000Q1- 2012Q4), which are available at Financial Analysis Information Retrieval System, at the Bank of Korea (BOK). We also retrieve the macroeconomic data from the Economic Statistics System, BOK.

(1) Before we proceed to estimate the econometric model, it is worthwhile to conduct a simple analysis on the difference between foreign and domestic banks in the Korean economy (Table 1). Domestic banks are observed to provide loans at a higher growth rate than foreign banks in terms of both mean and median. However foreign banks, although smaller in their market size, have higher liquidity and capitalization ratios, but earn lower profits than their domestic counterparts. The identified distinction between foreign banks and domestic banks in their bank characteristics confirms the necessity to control for these factors in order to isolate foreign banks' different behavior caused by their foreign ownership.

(2) Since some of the bank characteristics variables may be correlated with each other, they may generate the problem of multicollinearity if included in the model simultaneously. Accordingly we examine the pair-wise correlation between the bank characteristics variables, and do not observe substantially high correlation coefficients between these variables, which indicates little evidence on multicollinearity (See Table 1). 


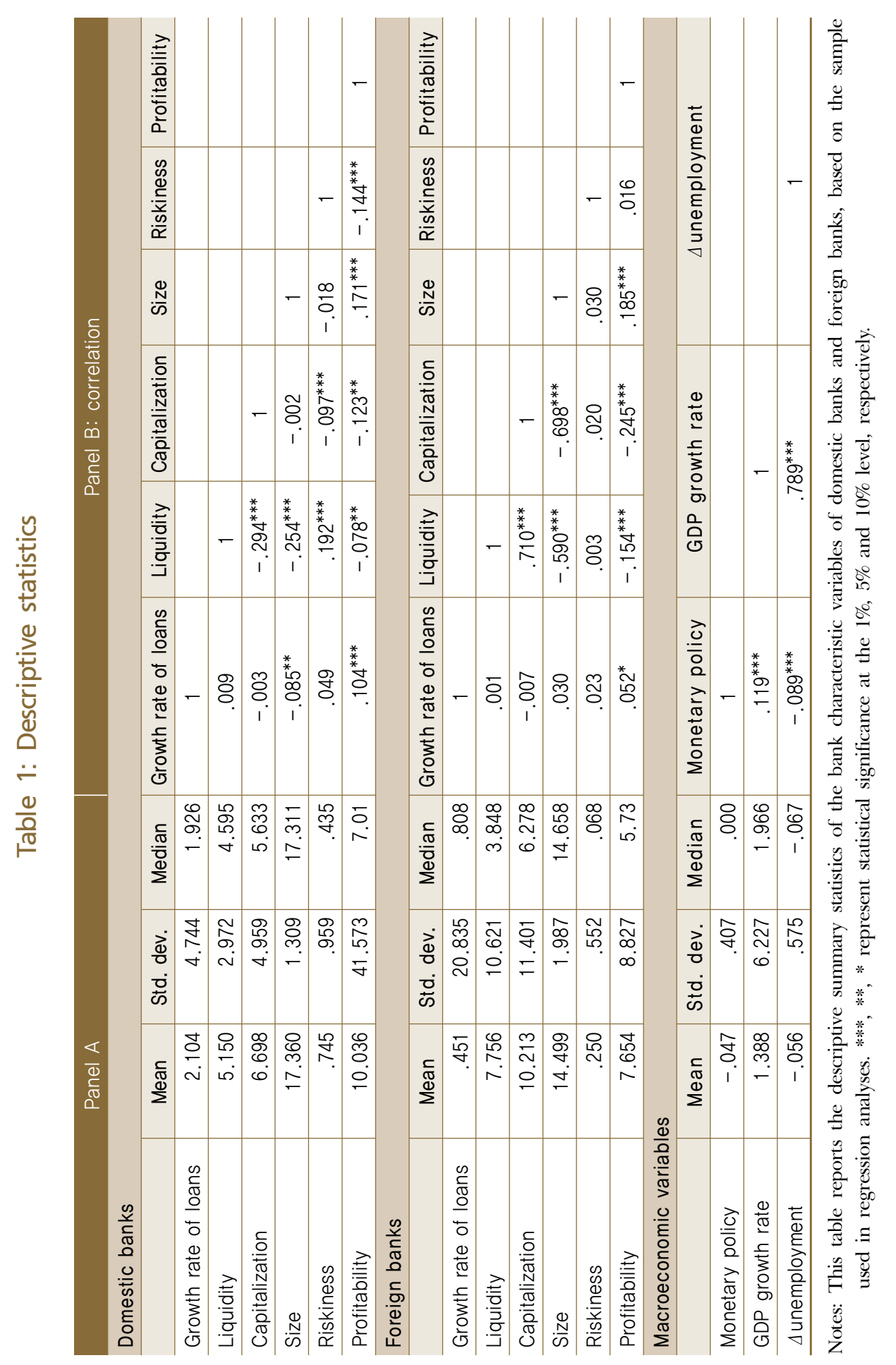




\section{Econometric methodology}

We estimate our empirical model using the system GMM estimator, following the methodology developed by Arellano and Bover (1995) and Blundell and Bond (1998), to address a possible concern on the endogeneity issue in determining loan growth. The system GMM estimator uses both level and differenced equations and instrumented the lagged dependent variable by using lagged differences for the level equation and lagged level for the differenced equation.

In all estimations, we control for a full set of time-specific effects and also control for the bank-specific effects. We obtain robust standard errors to correct for the heteroskedasticity across banks in the panel. We add four-quarter lags of the dependent variable in the system GMM estimation, whose results are discussed and reported in the next section.

\section{Estimation results}

\section{The baseline estimations}

The baseline regression results are reported in Table 2. The baseline estimations of the loan growth equation fit the data relatively well and the estimation results overall are reasonable. The coefficients on control variables, including bank characteristics and host country macroeconomic conditions, are not statistically significant during tranquil periods, while they turn to be statistically significant during the crisis period of 2008-2009. To save space, we only report the long-run elasticity, respectively in tranquil periods and the global financial crisis period. Meanwhile, we report the differences between the coefficients in non-crisis periods vs. crisis periods.

First, the coefficient on the long-run effect of monetary policy on lending (the stand-alone $\mathrm{mp}$ ) is negative as expected and statistically significant, suggesting that banks will increase (reduce) their loans when the BOK adopts a more expansionary (contractionary) monetary policy. Quantitatively, the coefficient is 9.993, which implies that a typical 25 basis point downward adjustment in the monetary policy base rate 
during tranquil periods will cause domestic banks to increase their lending growth rate by around $2.5 \%(=9.993 \times 0.25 \%)$ in the long run.

Second, we find the effect of monetary policy becomes more salient during the period of the global financial crisis of 2008-2009. Domestic banks will increase their lending growth rate by more than $14 \%$ with a 100 basis point downward adjustment in the Korean monetary policy, although the difference between the coefficient during tranquil periods $(-9.993)$ and crisis periods $(-14.578)$ is not detected to be statistically significant. ${ }^{3)}$ This finding suggests that domestic banks are increasingly sensitive to the unusually aggressive monetary expansion by the BOK during the crisis period.

Third, the Korean monetary policy also works effectively among foreign bank subsidiaries. A 100 basis point adjustment on the BOK base rate will cause foreign subsidiaries to change their credit growth rate by 12 percentage points in an expected direction during tranquil periods. This pattern of responses to changes in monetary policy by foreign bank subsidiaries is almost same as that of during the 2008-2009 global financial crisis. This result suggests the similarity in the lending behavior between by foreign bank subsidiaries and by domestic banks. However, we find significant evidence that foreign bank branches are much less sensitive to changes in the Korean monetary policy during the crisis period. The effect of monetary policy on lending by foreign bank branches in crisis is positive, instead of negative, and the difference from their responses during tranquil periods is statistically significant.

This finding suggests that foreign bank branches actually reduced their lending when the BOK lowered its base rate substantially to conduct aggressively expansionary monetary policy during the crisis period in Korea. However, the relatively low statistical significance (only 10 percent) could be caused by the inclusion of numerous interaction terms, which increase the correlation across regressors and the standard error of estimations. We investigate further on this finding in following sub-sections.

3) The difference is calculated as $\sum_{j=0}^{4} \kappa_{j} /\left(1-\sum_{j=1}^{4} \alpha_{j}\right)$. 


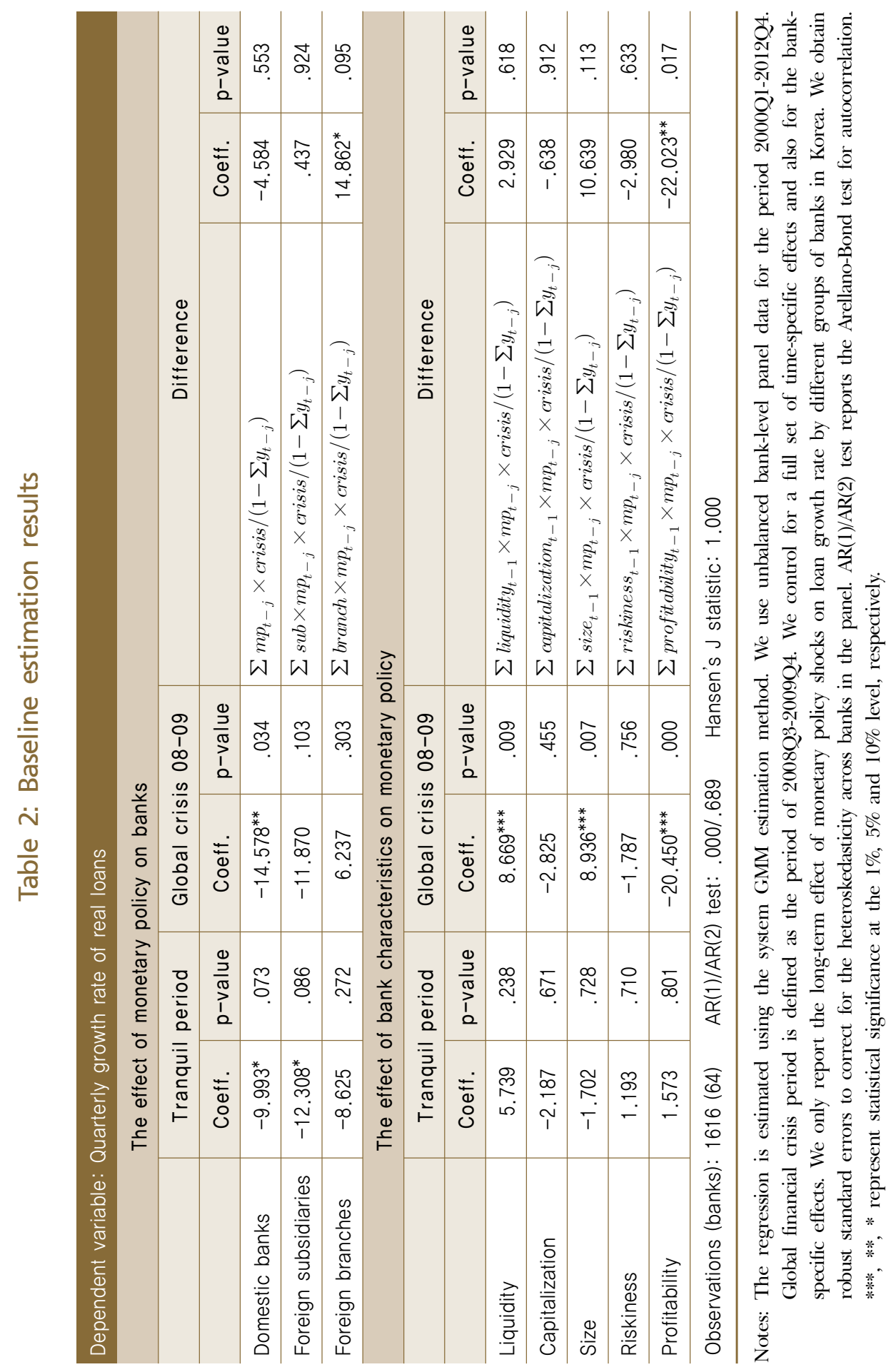




\section{$11 \quad$ BOK Working Paper No.2014-08 (2014.04)}

\section{Foreign bank branches: US bank branches vs. non-US bank branches}

We next divide branches of foreign banks in Korea into two groups, those established by banks headquartered in the U.S. and those established by parent banks in other countries. The reasons why we are interested in the comparison between US bank branches and non-US bank branches include: first, the global financial crisis of 2008-2009 started from the U.S. after it suffered from housing market bubble burst and the outbreak of the sub-prime mortgage crisis, and second, foreign banks from the U.S. have the largest market share in the Korean banking sector, and show largest inter-office transactions of funds between parent banks and their foreign subsidiaries or branches among those inter-office transactions by all US and non-US foreign banks. The estimation results are reported in Table 3 .

The results suggest that the inertia in foreign bank branches to the Korean monetary policy is mainly driven by American bank branches. They reduced their lending growth rate substantially when BOK lowered the base rate, indicated by the reported highly significant coefficient 19.670 . We find that both groups of foreign bank branches show very different responses to monetary policy shocks, especially during the 2008-2009 crisis than their domestic peers. The effect of changes in monetary policy on lending by foreign bank branches is negative during tranquil periods although not statistically significant. But the effect turns to be positive during the crisis period, implying both groups cut their lending albeit under a substantially lowered BOK base rate. However, we find statistically significant evidence only for American bank branches. The difference between their monetary policy responses in tranquil periods vs. crisis periods is notably statistically significant, while that for non-American bank branches is only marginally not significant.

In sum, the buffering effect of foreign banks on the monetary policy transmission mechanism in Korea are the most conspicuous by foreign bank branches whose parent banks are located in the U.S. among foreign banks from different country origin. 


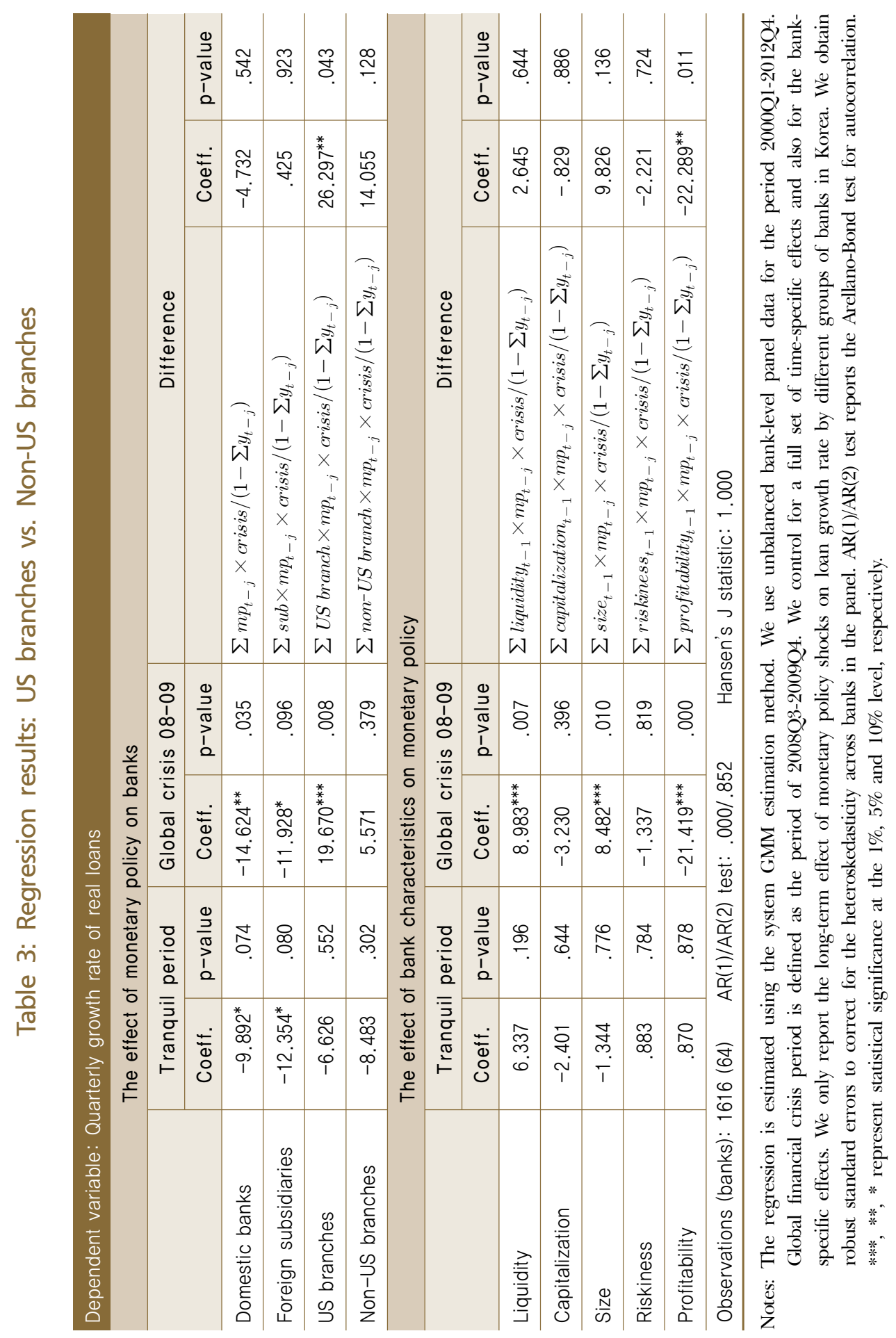




\section{Global vs. regional foreign bank branches}

In this section, we test if foreign bank branches would have different responses to changes in monetary policy in the host country, Korea, given the geographic scope of the conglomerates' operation. A global foreign bank is defined as a multinational financial institution whose headquarter or the majority of affiliates are located outside Asia. By contrast, a regional foreign bank is the one with both headquarters and main affiliates located in Asia. The global foreign banks are expected to be more exposed to the recent global financial crisis, and hence they probably would ship more funds toward their crisishit headquarters, leading to their foreign branches' more sluggish responses to host monetary policy.

The results of estimation are reported in Table 4. In the estimation, we replace the dummy, branch, by two alternative dummies, representing the branches of global foreign banks and the regional foreign banks, respectively. For simplicity, we only report the long-term effect of monetary policy shocks on the lending by different groups of banks in Korea.

The transmission of Korean monetary policy to domestic banks and foreign subsidiaries is found to be still effective in both tranquil and global financial crisis periods. The impact of Korean monetary policy is seemingly more pronounced during the global financial crisis period, although the difference between the tranquil and the crisis periods are not statistically significant. Foreign subsidiaries are found no variation in their sensitivity to domestic monetary policy between the two periods. By contrast, both global and regional foreign banks' branches show reversed responses to changes in Korean monetary policy in 2008-2009 by reducing the growth rate of their credit. As expected, the branches of global foreign banks reversed their lending more substantially than their counterparts of regional foreign banks, indicated by statistically significant differences between the sensitivity of their lending to monetary policy changes in non-crisis as well as crisis periods. Compared with Table 3, it is observed that the reversed reaction of global foreign bank branches to Korean monetary policy is milder than that of American bank branches. This is because the global crisis of 2008-2009 started in the U.S., and accordingly the global multinational banks originated from Europe and Japan are less severely affected by the financial crisis, compared to U.S. banks, thus only demanding less capital flows from their branches in Korea. 


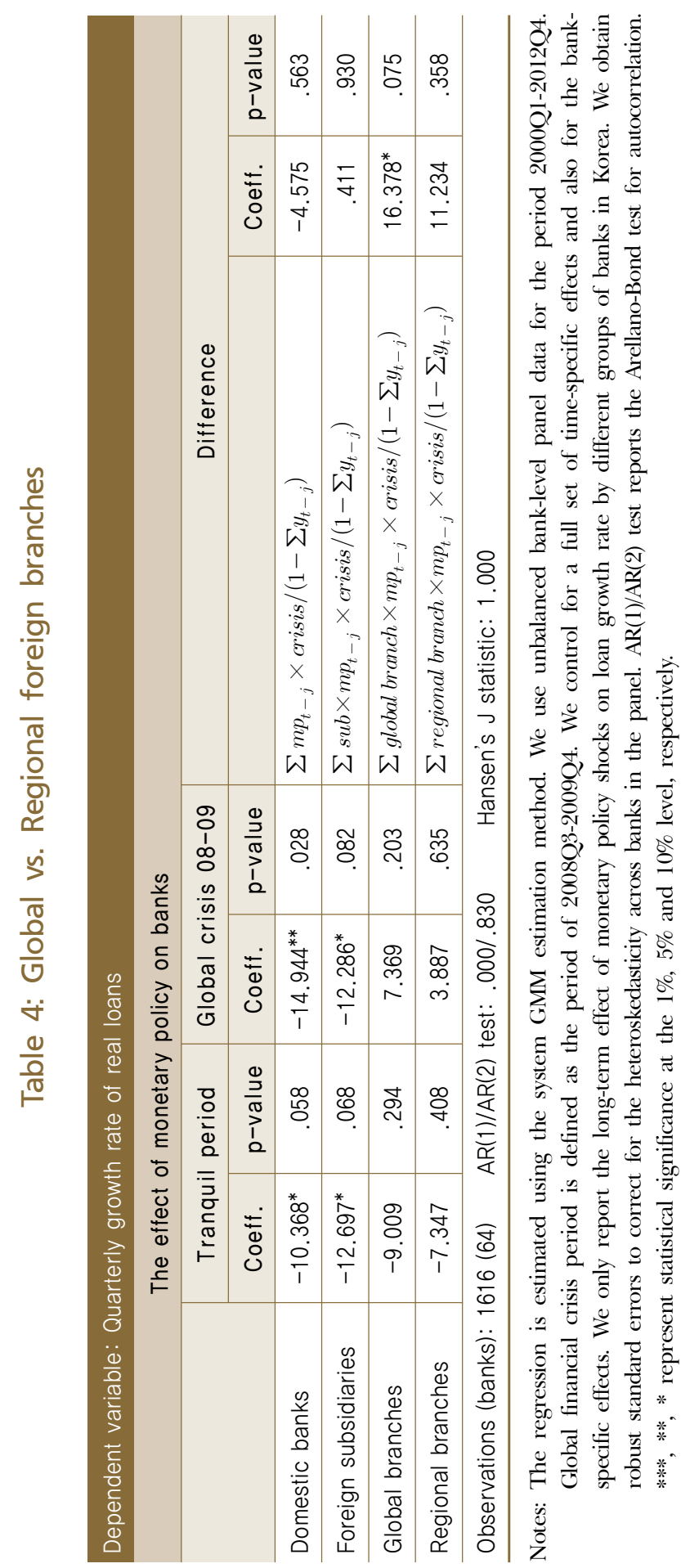




\section{Robustness tests}

In this section we conduct a number of robustness tests. We first widen the window of financial crisis from 2008Q3-2009Q4 to 2007Q3-2009Q4 to include the period of the subprime mortgage crisis in the U.S. The results are reported in the first panel of Table 5. Foreign bank branches' buffering force to host monetary policy is found more salient in the widened crisis period. During 2007-2009, a 100 basis point cut of base rate by BOK causes foreign branches to increase their lending by 8.711 percent, suggesting a credit growth rate reversion by 20.920 percent and this variation is highly statistically significant. The result seems to imply that foreign banks actually transfer their funds back to their headquarters before the global turmoil was triggered off by the failure of Lehman Brothers.

It can be argued that the estimates of the effects of branches' financial characteristics on their lending may be overstated since they may not be relevant. For example, since branches are not independent entities, there is no specific capital sufficiency requirement imposed independently on them and thus foreign bank branches' capital may not affect their lending decisions. Accordingly, in our second robustness test, we try to rule out the potentially biased effects of branches' capitalization by dropping the variable of capital from the estimation equation. Meanwhile, we also assume the profitability of branches, proxied by ROE, is not much relevant as a bank characteristic either. The results, as reported in Table 5, test 2, do not change our baseline findings qualitatively. Foreign branches are still found to cut down their credit growth when BOK lowered policy rates in the 2008-2009 financial crisis, and the difference from their behavior in the tranquil period is only marginally insignificant.

Finally, we try to increase the variation in our monetary policy indicator by substituting the first-order difference of the Korean money market rate for the change in BOK's policy rate. As reported in Table 5, test 3, the results are not much different from our previous finding. 


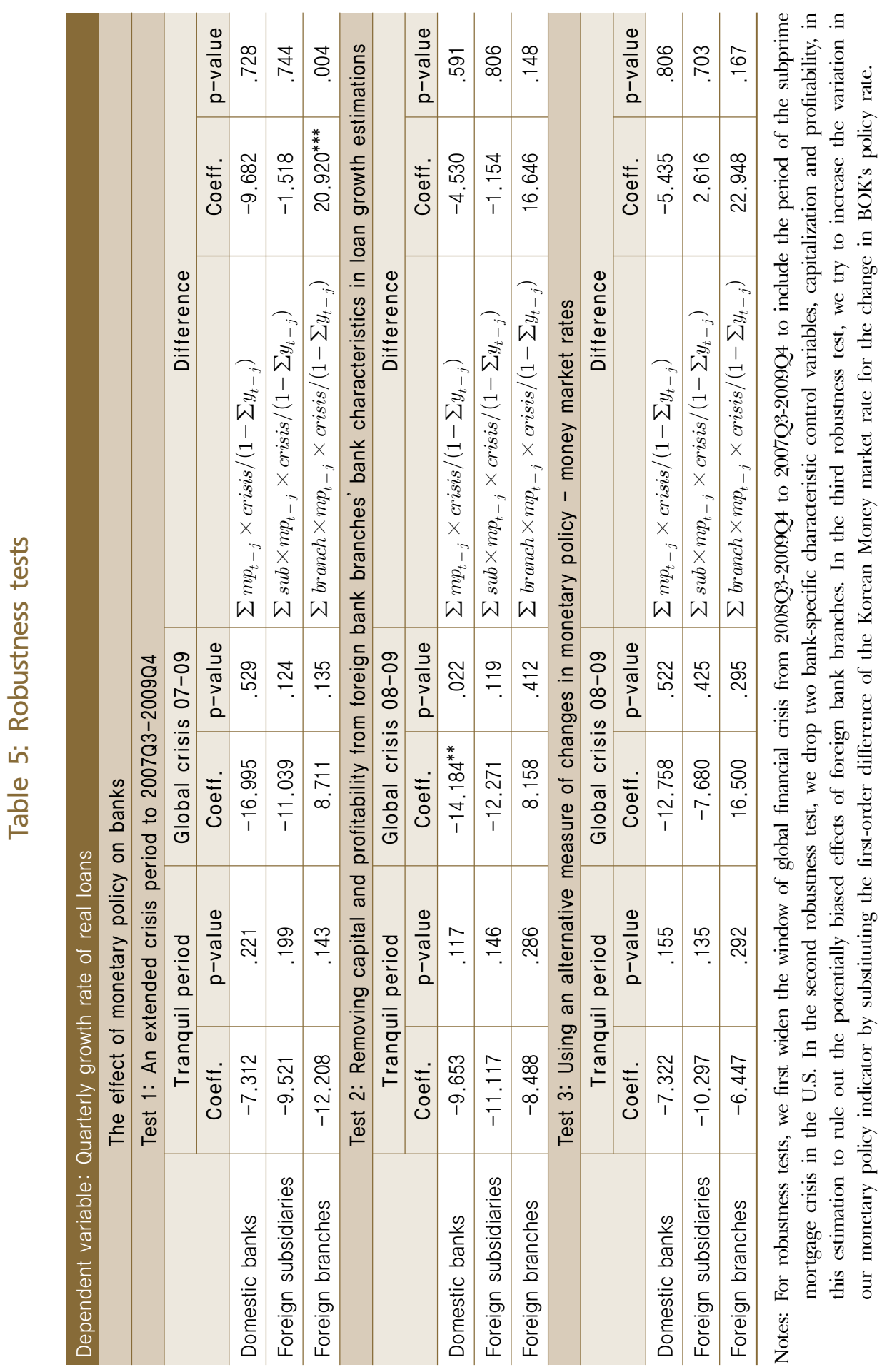




\section{Conclusion}

We examine the impact of foreign banks on the monetary policy transmission mechanism from the bank-lending channel perspective in the Korean economy during the period from 2000 to 2012, with a specific focus on the lending behavior by banks with different types of ownership. Using the bank-level panel data of the banking system in Korea, we find that there exist heterogeneous responses of loan growth by domestic banks and foreign-owned banks to changes in monetary policy in Korea during the recent global financial crisis of 2008-2009. In particular, during crisis periods, foreign banks play a buffering or even hampering role in affecting the monetary policy transmission mechanism by adjusting loan growth in a way opposite to domestic banks.

We present consistent evidence on the buffering impact of foreign banks on the effectiveness of the monetary policy transmission mechanism in Korea. This is more conspicuous for foreign bank branches than for foreign bank subsidiaries during the period of the global financial crisis of 2008-2009. Our further analyses show that this buffering effect is mostly driven by foreign bank branches whose parent banks are located in the U.S. One of the underlying reasons for the buffering effect by foreign bank branches is the existence of internal capital markets operated by multinational banks to overcome capital market frictions faced when the foreign banks finance their loans. Multinational banks establish internal capital markets and allocate their funds on global scale across their foreign subsidiaries and branches, which may affect the efficacy of monetary policy in host countries. ${ }^{4}$ )

Our findings suggest an important policy implication for both policy makers and banking regulators in Korea that, when the Bank of Korea conducts monetary policies - expansionary or contractionary - during crisis periods to bail them out from the credit crunch and spillover effects of financial shocks from abroad, it must take into account the buffering or hampering effects of foreign banks on the effectiveness of the monetary policy transmission mechanism. This paper presents evidence that this buffering effect is most likely created by foreign bank branches, among foreign banks with different types of ownership, operating banking activities in Korea.

4) For empirical evidence that internal capital markets do exist between multinational banks and their subsidiaries in emerging and developing economies, see Jeon and Wu (2013). 


\section{References}

Arena, M., C. Reinhart, and F. Vazquez (2007), "The Lending Channel in Emerging Economies: Are Foreign Banks Different?” IMF Working paper, No. 07/48.

Bernanke, B. and A. Blinder (1988), "Is It Money or Credit, or Both or Neither?

Credit, Money and Aggregate Demand," American Economic Review, Vol. 78 (2), pp. 435-439.

Bernanke, B. and A. Blinder (1992), "The Federal Fund Rate and the Channels of Monetary Transmission," American Economic Review, Vol. 82 (4), pp. 901-921.

Cetorelli, N. and L.S. Goldberg (2010), "Global Banks and International Shock Transmission: Evidence from the Crisis,” NBER Working paper, No. 15974.

Cetorelli, N. and L.S. Goldberg (2012a), "Follow the Money: Quantifying Domestic Effects of Foreign Bank Shocks in the Great Recession," American Economic Review, Vol. 102 (3), pp. 213-218.

Cetorelli, N. and L.S. Goldberg (2012b), "Banking Globalization and Monetary Transmission," The Journal of Finance, Vol. 67 (5), pp. 1811-1843.

Claessens, S., A. Demirgüç-Kunt, and H. Huizinga (2001), "How Does Foreign Entry Affect Domestic Banking Markets?" Journal of Banking and Finance, No. 25, pp. 891-911.

Claessens, S. and N. van Horen (2009), "Being a Foreigner among Domestic Banks: Asset or Liability?” IMF Working paper, WP/09/273.

Dages B.G., L.S. Goldberg, and D. Kinney (2000), "Foreign and Domestic Bank Participation in Emerging Markets: Lessons from Mexico and Argentina," Federal Reserve Bank of New York Economic Policy Review, September, pp. 17-36.

De Haas, R. and I. van Lelyveld (2006), "Foreign Banks and Credit Stability in Central and Eastern Europe: A Panel Data Analysis," Journal of Banking and Finance, No. 30, pp. 1927-1952.

De Haas, R. and I. van Lelyveld (2010), "Internal Capital Market and Lending by Multinational Bank Subsidiaries," Journal of Financial Intermediation, Vol. 19 (1), pp. 1-25. 
Demirgüç-Kunt, A. and H. Huizinga (2010), "Bank Activity and Funding Strategies: The Impact on Risk and Returns," Journal of Financial Economics, Vol. 98 (3), pp. 626-650.

Gambacorta, L. (2005), "Inside the Bank Lending Channel," European Economic Review, Vol. 49 (7), pp. 1737-1759.

Havrylchyk, O. and E. Jurzyk (2006), "Profitability of Foreign and Domestic Banks in Central and Eastern Europe: Does the Mode of Entry Matter?" LICOS Discussion Paper, No. 16606.

Hossain, M., P.K. Jain, and S. Mitra (2013), "State Ownership and Bank Equity in the Asia-Pacific Region," Pacific-Basin Finance Journal, No. 21, pp. 914-931.

Jain-Chandra, S., M.J. Kim, S.H. Park, and J. Shin (2013), "The Impact of Foreign Bank Deleveraging on Korea,” BOK working paper 2013-25, Bank of Korea: Seoul, Korea.

Jeon, B.N., M.P. Olivero, and J. Wu (2011), "Do Foreign Banks Increase Competition? Evidence from Emerging Asian and Latin American Banking Markets," Journal of Banking and Finance, Vol. 35(4), pp. 856-875.

Jeon, B.N., M.P. Olivero, and J. Wu (2013), "Multinational Banking and the International Transmission of Financial Shocks: Evidence from Foreign Bank Subsidiaries," Journal of Banking and Finance, Vol. 37(3), pp. 952-972.

Jeon, B.N. and J. Wu (2013), "Multinational Banks and Internal Capital Markets: Evidence from Bank-Level Panel Data in Emerging Economies," Working paper, Bennett S. LeBow College of Business, Drexel University.

Kashyap, A. and J. Stein (1995), "The Impact of Monetary Policy on Bank Balance Sheets," Carnegie Rochester Conference Series on Public Policy, Vol. 42 (1), pp. 151-195.

Kashyap, A. and J. Stein (2000), "What Do a Million Observations on Banks Say about the Transmission of Monetary Policy?” American Economic Review, Vol. 90 (3), pp. 407-428.

Kishan, R. and T. Opiela (2000), "Bank Size, Bank Capital and Bank Lending Channel," Journal of Money, Credit and Banking, Vol. 32 (1), pp. 121-141. 
Martinez Peria, M.S., A. Powell, and I. Vladkova-Hollar (2005), "Banking on Foreigners: The Behavior of International Bank Claims on Latin America, 1985-2000," IMF Staff Papers, Vol. 52 (3), pp. 430-461.

McCauley, R.N. and J. Zukunft (2008), "Asian Banks and the International Interbank Market," BIS Quarterly Review, June, pp. 67-79.

Mian, A. (2003), "Foreign, Private Domestic, and Government Banks: New Evidence from Emerging Markets," University of Chicago Working paper.

Mihaljek, D. (2010), "Domestic Bank Intermediation in Emerging Market Economies During the Crisis: Locally Owned Versus Foreign-Owned Banks," BIS Paper, No. 54 .

Milesi-Ferretti, G. and C. Tille (2011), "The Great Retrenchment: International Capital Flows During the Global Financial Crisis," Economic Policy, No. 55, pp. 285-342.

Van Horen, N. (2007), "Foreign Banking in Developing Countries: Origin Matters," Emerging Markets Review, Vol. 8 (2), pp. 81-105.

Vogel, U. and A. Winkler (2011), "Foreign Banks and Financial Stability in Emerging Markets: Evidence from the Global Financial Crisis," Frankfurt School of Finance \& Management Working paper, No. 149.

Wu, J., B.N. Jeon, and A. Luca (2011), "Foreign Bank Penetration and the Lending Channel in Emerging Economies: Evidence from Bank-Level Panel Data," Journal of International Money and Finance, Vol. 30 (6), pp. 1128-1156. 


\section{Appendix 1: The BOK base rate and bank loans}

Figure A-1: The BOK base rate, 2000-2012

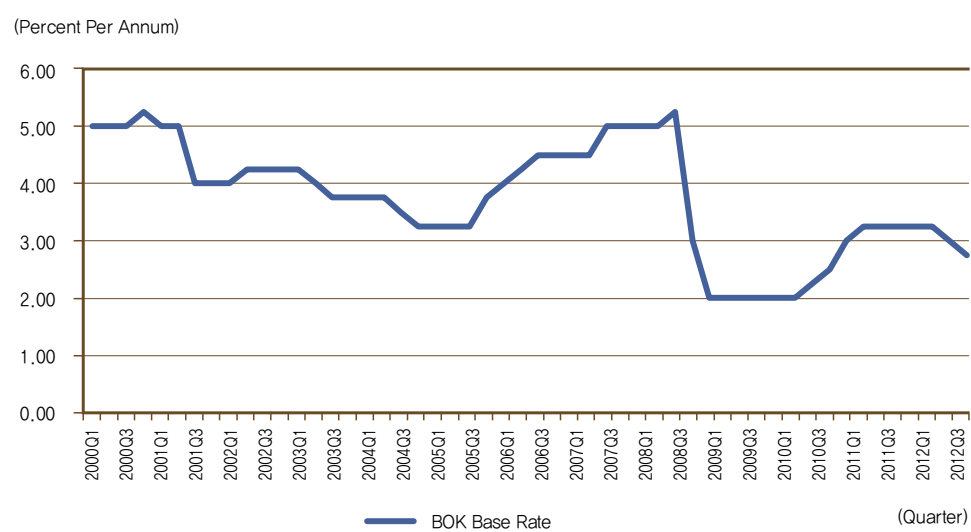

Notes: Quarterly data expressed in percentage points. The interest rate taken as monetary policy indicator is the base rate of the Bank of Korea in the period of 2000Q1-2012Q4.

Figure A-2: Bank loans by domestic banks and foreign banks in Korea, 2000-2012

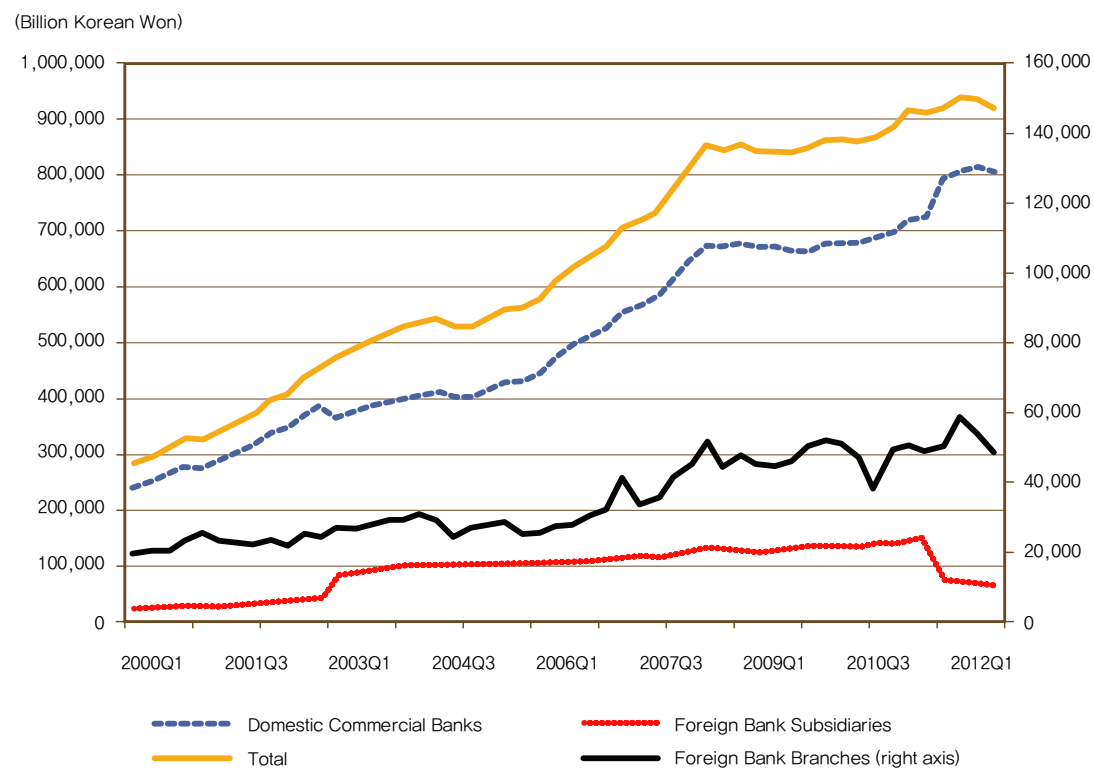

Notes: Quarterly data expressed in Billion Korean Won. This figure shows the level of loans by different groups of banks in Korea in the period of 2000Q1-2012Q4. 


\section{Appendix 2: List of banks by type of ownership in Korea, 2000-2012}

(a) Domestic Commercial Banks in Korea, 2000-2012

\begin{tabular}{|c|c|c|c|c|c|c|c|c|c|}
\hline 2000 & \multicolumn{2}{|l|}{2001} & \multicolumn{2}{|c|}{2002} & \multicolumn{2}{|c|}{2003} & \multicolumn{2}{|r|}{2004} & \multirow{2}{*}{$\begin{array}{l}2005 \\
\text { Woori Bank }\end{array}$} \\
\hline Woori Bank & \multicolumn{2}{|l|}{ Woori Bank } & \multicolumn{2}{|l|}{ Woori Bank } & \multicolumn{2}{|c|}{ Woori Bank } & \multicolumn{2}{|c|}{ Woori Bank } & \\
\hline Chohung Bank & \multicolumn{2}{|l|}{ Chohung Bank } & \multicolumn{2}{|c|}{ Chohung Bank } & \multicolumn{2}{|c|}{ Chohung Bank } & \multicolumn{2}{|c|}{ Chohung Bank } & Chohung Bank \\
\hline Seoul Bank & \multicolumn{2}{|l|}{ Seoul Bank } & \multicolumn{2}{|l|}{ Seoul Bank } & \multicolumn{2}{|c|}{ Shinhan Bank(old) } & \multicolumn{2}{|c|}{ Shinhan Bank(old) } & Shinhan Bank(old) \\
\hline Shinhan Bank(old) & \multicolumn{2}{|c|}{ Shinhan Bank(old) } & \multicolumn{2}{|c|}{ Shinhan Bank(old) } & \multicolumn{2}{|c|}{ Kookmin Bank } & \multicolumn{2}{|c|}{ Kookmin Bank } & Kookmin Bank \\
\hline Hana Bank(old) & \multicolumn{2}{|c|}{ Hana Bank(old) } & \multicolumn{2}{|c|}{ Hana Bank(old) } & \multicolumn{2}{|c|}{ Hana Bank } & Hana & Bank & Hana Bank \\
\hline $\begin{array}{l}\text { Peace Bank of } \\
\text { Korea }\end{array}$ & $\begin{array}{l}\text { Peace Bank o } \\
\text { Korea }\end{array}$ & & Kookmin Be & & Daegu E & Bank & Daegu & u Bank & Daegu Bank \\
\hline Kookmin Bank(old) & Kookmin Bank & (old) & Hana Bank & & Busan B & Bank & Busan & n Bank & Busan Bank \\
\hline $\begin{array}{l}\text { Housing \& } \\
\text { Commercial Bank }\end{array}$ & $\begin{array}{l}\text { Housing \& } \\
\text { Commercial Bc }\end{array}$ & & Daegu Ban & & Kwangju & Bank & Kwans & gju Bank & Kwangju Bank \\
\hline Daegu Bank & Kookmin Bank & & Busan Bank & & Jeju Ba & & Jeju E & Bank & Jeju Bank \\
\hline Busan Bank & Daegu Bank & & Kwangju Ba & & Jeonbuk & s Bank & Jeonb & ouk Bank & Jeonbuk Bank \\
\hline Kwangju Bank & Busan Bank & & Jeju Bank & & Kyongn & am Bank & Kyong & gnam Bank & Kyongnam Bank \\
\hline Jeju Bank & Kwangju Bank & & Jeonbuk Ba & & & & & & \\
\hline Jeonbuk Bank & Jeju Bank & & Kyongnam & 3ank & & & & & \\
\hline Kyongnam Bank & Jeonbuk Bank & & $\begin{array}{l}\text { Korea Exch } \\
\text { Bank }\end{array}$ & ange & & & & & \\
\hline $\begin{array}{l}\text { Korea Exchange } \\
\text { Bank }\end{array}$ & Kyongnam Bar & & & & & & & & \\
\hline & $\begin{array}{l}\text { Korea Exchan } \\
\text { Bank }\end{array}$ & & & & & & & & \\
\hline 15 & 16 & & 14 & & & 11 & & 11 & 11 \\
\hline 2006 & 2007 & & 2008 & & 09 & 2010 & & 2011 & 2012 \\
\hline Woori Bank & Woori Bank & & ri Bank & Woori & & Woori Bank & & Woori Bank & Woori Bank \\
\hline Chohung Bank & Kookmin Bank & & kmin Bank & Kookm & Bank & Kookmin Bank & & Kookmin Bank & Kookmin Bank \\
\hline $\begin{array}{l}\text { Shinhan } \\
\text { Bank(old) }\end{array}$ & Hana Bank & & Bank & Hana & & Hana Bank & & Hana Bank & Hana Bank \\
\hline Kookmin Bank & Shinhan Bank & & han Bank & Shinhe & Bank & Shinhan Bank & & Shinhan Bank & Shinhan Bank \\
\hline Hana Bank & Daegu Bank & & gu Bank & Daegu & 3ank & Daegu Bank & & Daegu Bank & Daegu Bank \\
\hline Shinhan Bank & Busan Bank & & an Bank & Busan & ank & Busan Bank & & Busan Bank & Busan Bank \\
\hline Daegu Bank & Kwangju Bank & & ngju Bank & Kwang & Bank & Kwangju Bank & & Kwangju Bank & Kwangju Bank \\
\hline Busan Bank & Jeju Bank & & Bank & Jeju B & & Jeju Bank & & Jeju Bank & Jeju Bank \\
\hline Kwangju Bank & Jeonbuk Bank & & ibuk Bank & Jeonb & Bank & Jeonbuk Bank & & Jeonbuk Bank & Jeonbuk Bank \\
\hline Jeju Bank & Kyongnam Bank & & gnam Bank & Kyong & am Bank & Kyongnam Ban & ank & Kyongnam Bank & Kyongnam Bank \\
\hline Jeonbuk Bank & & & & & & & & & $\begin{array}{l}\text { Korea Exchange } \\
\text { Bank }\end{array}$ \\
\hline Kyongnam Bank & & & & & & & & & \\
\hline 12 & 10 & & 10 & & 0 & 10 & & 10 & 11 \\
\hline
\end{tabular}

Notes: Korea Exchange Bank was acquired in 2003 by Lone Star Funds, a private U.S. equity fund, and it was incorporated into Hana Financial Group, a domestic financial holding company, in 2012. 
(b) Foreign Bank Branches in Korea, 2000-2005

\begin{tabular}{|c|c|c|c|c|c|}
\hline 2000 & 2001 & 2002 & 2003 & 2004 & 2005 \\
\hline Standard Chartered & Standard Chartered & Standard Chartered & Standard Chartered & Standard Chartered & Standard Chartered \\
\hline $\begin{array}{l}\text { Credit Agricole } \\
\text { Corporate And } \\
\text { Investment Bank }\end{array}$ & $\begin{array}{l}\text { Credit Agricole } \\
\text { Corporate And } \\
\text { Investment Bank }\end{array}$ & $\begin{array}{l}\text { Credit Agricole } \\
\text { Corporate And } \\
\text { Investment Bank }\end{array}$ & $\begin{array}{l}\text { Credit Agricole } \\
\text { Corporate And } \\
\text { Investment Bank }\end{array}$ & $\begin{array}{l}\text { Credit Agricole } \\
\text { Corporate And } \\
\text { Investment Bank }\end{array}$ & $\begin{array}{l}\text { Credit Agricole } \\
\text { Corporate And } \\
\text { Investment Bank }\end{array}$ \\
\hline Arab Bank & Arab Bank & Arab Bank & Arab Bank & BNP Paribas & BNP Paribas \\
\hline BNPParibas & BNPParibas & BNPParibas & BNPParibas & ING Bank & ING Bank \\
\hline ING Bank & ING Bank & ING Bank & ING Bank & Credit Lyonnais & UBAF \\
\hline Credit Lyonnais & Credit Lyonnais & Credit Lyonnais & Credit Lyonnais & UBAF & DBS Bank \\
\hline UBAF & UBAF & UBAF & UBAF & DBS Bank & UFJ \\
\hline DBS Bank & DBS Bank & DBS Bank & DBS Bank & UFJ & Societe Generale \\
\hline UFJ & UFJ & UFJ & UFJ & Societe Generale & $\begin{array}{l}\text { Union Bank of } \\
\text { California }\end{array}$ \\
\hline Societe Generale & Societe Generale & Societe Generale & Societe Generale & $\begin{array}{l}\text { Union Bank of } \\
\text { California }\end{array}$ & $\begin{array}{l}\text { Australia and New } \\
\text { Zealand Bank(ANZ) }\end{array}$ \\
\hline $\begin{array}{l}\text { Union Bank of } \\
\text { California }\end{array}$ & $\begin{array}{l}\text { Union Bank of } \\
\text { California }\end{array}$ & $\begin{array}{l}\text { Union Bank of } \\
\text { California }\end{array}$ & $\begin{array}{l}\text { Union Bank of } \\
\text { California }\end{array}$ & $\begin{array}{l}\text { Australia and New } \\
\text { Zealand Bank(ANZ) }\end{array}$ & $\begin{array}{l}\text { Oversea-Chinese } \\
\text { Banking } \\
\text { Corporation }\end{array}$ \\
\hline $\begin{array}{l}\text { Australia and New } \\
\text { Zealand Bank(ANZ) }\end{array}$ & $\begin{array}{l}\text { Australia and New } \\
\text { Zealand Bank(ANZ) }\end{array}$ & $\begin{array}{l}\text { Australia and New } \\
\text { Zealand Bank(ANZ) }\end{array}$ & $\begin{array}{l}\text { Australia and New } \\
\text { Zealand Bank(ANZ) }\end{array}$ & $\begin{array}{l}\text { Oversea-Chinese } \\
\text { Banking } \\
\text { Corporation }\end{array}$ & Bank of China \\
\hline $\begin{array}{l}\text { Oversea-Chinese } \\
\text { Banking } \\
\text { Corporation }\end{array}$ & $\begin{array}{l}\text { Oversea-Chinese } \\
\text { Banking } \\
\text { Corporation }\end{array}$ & $\begin{array}{l}\text { Oversea-Chinese } \\
\text { Banking } \\
\text { Corporation }\end{array}$ & $\begin{array}{l}\text { Oversea-Chinese } \\
\text { Banking } \\
\text { Corporation }\end{array}$ & Bank of China & Credit Suisse \\
\hline Bank of China & Bank of China & Bank of China & Bank of China & Credit Suisse & $\begin{array}{l}\text { AmericanExpressBa } \\
\mathrm{nk}\end{array}$ \\
\hline Morgan & Morgan & Credit Suisse & Credit Suisse & $\begin{array}{l}\text { AmericanExpressBa } \\
\text { nk }\end{array}$ & State Street \\
\hline Credit Suisse & Credit Suisse & $\begin{array}{l}\text { American Express } \\
\text { Bank }\end{array}$ & $\begin{array}{l}\text { American Express } \\
\text { Bank }\end{array}$ & State Street & $\begin{array}{l}\text { National Australia } \\
\text { Bank(NAB) }\end{array}$ \\
\hline $\begin{array}{l}\text { American Express } \\
\text { Bank }\end{array}$ & $\begin{array}{l}\text { American Express } \\
\text { Bank }\end{array}$ & State Street & State Street & $\begin{array}{l}\text { National Australia } \\
\text { Bank(NAB) }\end{array}$ & Bank of Novascotia \\
\hline $\begin{array}{l}\text { National Bank of } \\
\text { Canada }\end{array}$ & State Street & $\begin{array}{l}\text { National Australia } \\
\text { Bank(NAB) }\end{array}$ & $\begin{array}{l}\text { National Australia } \\
\text { Bank(NAB) }\end{array}$ & Bank of Novascotia & $\begin{array}{l}\text { Bank of NY Mellon } \\
\text { (BNY Mellon) }\end{array}$ \\
\hline $\begin{array}{l}\text { National Australia } \\
\text { Bank(NAB) }\end{array}$ & $\begin{array}{l}\text { National Australia } \\
\text { Bank(NAB) }\end{array}$ & Bank of Novascotia & Bank of Novascotia & $\begin{array}{l}\text { Bank of NY Mellon } \\
\text { (BNY Mellon) }\end{array}$ & $\begin{array}{l}\text { Mizuho Corporate } \\
\text { Bank }\end{array}$ \\
\hline Bank of Novascotia & Bank of Novascotia & $\begin{array}{l}\text { Bank of NY Mellon } \\
\text { (BNY Mellon) }\end{array}$ & $\begin{array}{l}\text { Bank of NY Mellon } \\
\text { (BNY Mellon) }\end{array}$ & $\begin{array}{l}\text { Mizuho Corporate } \\
\text { Bank }\end{array}$ & $\begin{array}{l}\text { United Overseas } \\
\text { Bank }\end{array}$ \\
\hline $\begin{array}{l}\text { Bank of NY Mellon } \\
\text { (BNY Mellon) }\end{array}$ & $\begin{array}{l}\text { Bank of NY Mellon } \\
\text { (BNY Mellon) }\end{array}$ & $\begin{array}{l}\text { Mizuho Corporate } \\
\text { Bank }\end{array}$ & $\begin{array}{l}\text { Mizuho Corporate } \\
\text { Bank }\end{array}$ & $\begin{array}{l}\text { United Overseas } \\
\text { Bank }\end{array}$ & Deutsche Bank \\
\hline $\begin{array}{l}\text { Mizuho Corporate } \\
\text { Bank }\end{array}$ & $\begin{array}{l}\text { Mizuho Corporate } \\
\text { Bank }\end{array}$ & $\begin{array}{l}\text { United Overseas } \\
\text { Bank }\end{array}$ & $\begin{array}{l}\text { United Overseas } \\
\text { Bank }\end{array}$ & Deutsche Bank & $\begin{array}{l}\text { BankofTokyo-Mitsu } \\
\text { bishiUFJ }\end{array}$ \\
\hline $\begin{array}{l}\text { United Overseas } \\
\text { Bank }\end{array}$ & $\begin{array}{l}\text { United Overseas } \\
\text { Bank }\end{array}$ & Deutsche Bank & Deutsche Bank & $\begin{array}{l}\text { Bank of } \\
\text { Tokyo-Mitsubishi } \\
\text { UFJ }\end{array}$ & Metrobank \\
\hline
\end{tabular}




\begin{tabular}{|c|c|c|c|c|c|}
\hline 2000 & 2001 & 2002 & 2003 & 2004 & 2005 \\
\hline Deutsche Bank & Deutsche Bank & $\begin{array}{l}\text { Bank of } \\
\text { Tokyo-Mitsubishi } \\
\text { UFJ }\end{array}$ & $\begin{array}{l}\text { Bank of } \\
\text { Tokyo-Mitsubishi } \\
\text { UFJ }\end{array}$ & Metrobank & Bank Mellat \\
\hline $\begin{array}{l}\text { Bank of } \\
\text { Tokyo-Mitsubishi } \\
\text { UFJ }\end{array}$ & $\begin{array}{l}\text { Bank of } \\
\text { Tokyo-Mitsubishi } \\
\text { UFJ }\end{array}$ & Metrobank & Metrobank & Bank Mellat & $\begin{array}{l}\text { Sumitomo Mitsui } \\
\text { Bank Ltd. }\end{array}$ \\
\hline Metrobank & Metrobank & Bank Mellat & Bank Mellat & $\begin{array}{l}\text { Sumitomo Mitsui } \\
\text { Bank Ltd. }\end{array}$ & Barclays \\
\hline $\begin{array}{l}\text { Sumitomo Mitsui } \\
\text { Bank Ltd. }\end{array}$ & Bank Mellat & $\begin{array}{l}\text { Sumitomo Mitsui } \\
\text { Bank Ltd. }\end{array}$ & $\begin{array}{l}\text { Sumitomo Mitsui } \\
\text { Bank Ltd. }\end{array}$ & Barclays & $\begin{array}{l}\text { Bank of America } \\
\text { Corporation }\end{array}$ \\
\hline $\begin{array}{l}\text { Bank of America } \\
\text { Corporation }\end{array}$ & $\begin{array}{l}\text { Sumitomo Mitsui } \\
\text { Bank Ltd. }\end{array}$ & Barclays & Barclays & $\begin{array}{l}\text { Bank of America } \\
\text { Corporation }\end{array}$ & Yamaguchi Bank \\
\hline $\begin{array}{l}\text { Bank One } \\
\text { Corporation }\end{array}$ & $\begin{array}{l}\text { Bank of America } \\
\text { Corporation }\end{array}$ & $\begin{array}{l}\text { Bank of America } \\
\text { Corporation }\end{array}$ & $\begin{array}{l}\text { Bank of America } \\
\text { Corporation }\end{array}$ & $\begin{array}{l}\text { Bank One } \\
\text { Corporation }\end{array}$ & RBS \\
\hline Citibank & $\begin{array}{l}\text { Bank One } \\
\text { Corporation }\end{array}$ & $\begin{array}{l}\text { Bank One } \\
\text { Corporation }\end{array}$ & $\begin{array}{l}\text { Bank One } \\
\text { Corporation }\end{array}$ & Citi bank & $\begin{array}{l}\text { Indian Overseas } \\
\text { Bank }\end{array}$ \\
\hline Asahi Bank & Citibank & Citibank & Citibank & Yamaguchi Bank & $\begin{array}{l}\text { Industrial and } \\
\text { Commercial Bank of } \\
\text { China Limited }\end{array}$ \\
\hline Yamaguchi Bank & Asahi Bank & Yamaguchi Bank & Yamaguchi Bank & RBS & $\begin{array}{l}\text { China Construction } \\
\text { Bank }\end{array}$ \\
\hline RBS & Yamaguchi Bank & RBS & RBS & $\begin{array}{l}\text { Indian Overseas } \\
\text { Bank }\end{array}$ & $\begin{array}{l}\text { J.P. Morgan Chase } \\
\text { and Corporation }\end{array}$ \\
\hline $\begin{array}{l}\text { Indian Overseas } \\
\text { Bank }\end{array}$ & RBS & $\begin{array}{l}\text { Indian Overseas } \\
\text { Bank }\end{array}$ & $\begin{array}{l}\text { Indian Overseas } \\
\text { Bank }\end{array}$ & $\begin{array}{l}\text { Industrial and } \\
\text { Commercial Bank of } \\
\text { China Limited }\end{array}$ & $\begin{array}{l}\text { National Bank of } \\
\text { Pakistan }\end{array}$ \\
\hline $\begin{array}{l}\text { Industrial and } \\
\text { Commercial Bank of } \\
\text { China Limited }\end{array}$ & $\begin{array}{l}\text { Indian Overseas } \\
\text { Bank }\end{array}$ & $\begin{array}{l}\text { Industrial and } \\
\text { Commercial Bank of } \\
\text { China Limited }\end{array}$ & $\begin{array}{l}\text { Industrial and } \\
\text { Commercial Bank of } \\
\text { China Limited }\end{array}$ & $\begin{array}{l}\text { China Construction } \\
\text { Bank }\end{array}$ & WellsFargo \\
\hline $\begin{array}{l}\text { J.P. Morgan Chase } \\
\text { and Corporation }\end{array}$ & $\begin{array}{l}\text { Industrial and } \\
\text { Commercial Bank of } \\
\text { China Limited }\end{array}$ & $\begin{array}{l}\text { J.P. Morgan Chase } \\
\text { and Corporation }\end{array}$ & $\begin{array}{l}\text { J.P. Morgan Chase } \\
\text { and Corporation }\end{array}$ & $\begin{array}{l}\text { J.P. Morgan Chase } \\
\text { and Corporation }\end{array}$ & HSBC \\
\hline Paribas & $\begin{array}{l}\text { J.P. Morgan Chase } \\
\text { and Corporation }\end{array}$ & $\begin{array}{l}\text { National Bank of } \\
\text { Pakistan }\end{array}$ & $\begin{array}{l}\text { National Bank of } \\
\text { Pakistan }\end{array}$ & $\begin{array}{l}\text { National Bank of } \\
\text { Pakistan }\end{array}$ & UBS Bank \\
\hline $\begin{array}{l}\text { National Bank of } \\
\text { Pakistan }\end{array}$ & $\begin{array}{l}\text { National Bank of } \\
\text { Pakistan }\end{array}$ & Wells Fargo & Wells Fargo & Wells Fargo & $\begin{array}{l}\text { Bank Of } \\
\text { Communications }\end{array}$ \\
\hline Wells Fargo & Wells Fargo & Fleet National Bank & HSBC & HSBC & Morgan Stanley \\
\hline Fleet National Bank & Fleet National Bank & HSBC & UBS Bank & UBS Bank & \\
\hline Bank of Hawaii & Bank of Hawaii & Fuji Bank & & & \\
\hline HSBC & HSBC & UBS Bank & & & \\
\hline $\begin{array}{l}\text { Overseas Union } \\
\text { Bank Limited }\end{array}$ & $\begin{array}{l}\text { Overseas Union } \\
\text { Bank Limited }\end{array}$ & & & & \\
\hline Fuji Bank & Fuji Bank & & & & \\
\hline UBS Bank & UBS Bank & & & & \\
\hline 45 & 45 & 42 & 40 & 40 & 39 \\
\hline
\end{tabular}


(c) Foreign Bank Branches in Korea, 2006-2012

\begin{tabular}{|c|c|c|c|c|c|c|}
\hline 2006 & 2007 & 2008 & 2009 & 2010 & 2011 & 2012 \\
\hline $\begin{array}{l}\text { Credit Agricole } \\
\text { Corporate And } \\
\text { Investment Bank }\end{array}$ & $\begin{array}{l}\text { Credit Agricole } \\
\text { Corporate And } \\
\text { Investment Bank }\end{array}$ & $\begin{array}{l}\text { Credit Agricole } \\
\text { Corporate And } \\
\text { Investment Bank }\end{array}$ & $\begin{array}{l}\text { Credit Agricole } \\
\text { Corporate And } \\
\text { Investment Bank }\end{array}$ & $\begin{array}{l}\text { Credit Agricole } \\
\text { Corporate And } \\
\text { Investment Bank }\end{array}$ & $\begin{array}{l}\text { Credit Agricole } \\
\text { Corporate And } \\
\text { Investment Bank }\end{array}$ & $\begin{array}{l}\text { Credit Agricole } \\
\text { Corporate And } \\
\text { Investment Bank }\end{array}$ \\
\hline BNP Paribas & BNP Paribas & BNP Paribas & BNP Paribas & BNP Paribas & BNP Paribas & BNP Paribas \\
\hline ING Bank & ING Bank & ING Bank & ING Bank & ING Bank & ING Bank & ING Bank \\
\hline UBAF & UBAF & UBAF & UBAF & UBAF & UBAF & UBAF \\
\hline DBS Bank & DBS Bank & DBS Bank & DBS Bank & DBS Bank & DBS Bank & DBS Bank \\
\hline Societe Generale & Societe Generale & Societe Generale & Societe Generale & Societe Generale & Societe Generale & Societe Generale \\
\hline $\begin{array}{l}\text { Union Bank of } \\
\text { California }\end{array}$ & $\begin{array}{l}\text { Australia and } \\
\text { New Zealand } \\
\text { Bank(ANZ) }\end{array}$ & $\begin{array}{l}\text { Australia and } \\
\text { New Zealand } \\
\text { Bank(ANZ) }\end{array}$ & $\begin{array}{l}\text { Australia and } \\
\text { New Zealand } \\
\text { Bank(ANZ) }\end{array}$ & $\begin{array}{l}\text { Australia and } \\
\text { New Zealand } \\
\text { Bank(ANZ) }\end{array}$ & $\begin{array}{l}\text { Australia and } \\
\text { New Zealand } \\
\text { Bank(ANZ) }\end{array}$ & $\begin{array}{l}\text { Australia and } \\
\text { New Zealand } \\
\text { Bank(ANZ) }\end{array}$ \\
\hline $\begin{array}{l}\text { Australia and } \\
\text { New Zealand } \\
\text { Bank(ANZ) }\end{array}$ & $\begin{array}{l}\text { Oversea-Chinese } \\
\text { Banking } \\
\text { Corporation }\end{array}$ & $\begin{array}{l}\text { Oversea-Chinese } \\
\text { Banking } \\
\text { Corporation }\end{array}$ & $\begin{array}{l}\text { Oversea-Chinese } \\
\text { Banking } \\
\text { Corporation }\end{array}$ & $\begin{array}{l}\text { Oversea-Chinese } \\
\text { Banking } \\
\text { Corporation }\end{array}$ & $\begin{array}{l}\text { Oversea-Chinese } \\
\text { Banking } \\
\text { Corporation }\end{array}$ & $\begin{array}{l}\text { Oversea-Chinese } \\
\text { Banking } \\
\text { Corporation }\end{array}$ \\
\hline $\begin{array}{l}\text { Oversea-Chines } \\
\text { e Banking } \\
\text { Corporation }\end{array}$ & Bank of China & Bank of China & Bank of China & Bank of China & Bank of China & Bank of China \\
\hline Bank of China & Credit Suisse & Credit Suisse & Credit Suisse & Credit Suisse & Credit Suisse & Credit Suisse \\
\hline Credit Suisse & $\begin{array}{l}\text { American } \\
\text { Express Bank }\end{array}$ & $\begin{array}{l}\text { American } \\
\text { Express Bank }\end{array}$ & State Street & State Street & State Street & State Street \\
\hline $\begin{array}{l}\text { American } \\
\text { Express Bank }\end{array}$ & State Street & State Street & $\begin{array}{l}\text { Bank of } \\
\text { Novascotia }\end{array}$ & $\begin{array}{l}\text { Bank of } \\
\text { Novascotia }\end{array}$ & $\begin{array}{l}\text { Bank of } \\
\text { Novascotia }\end{array}$ & $\begin{array}{l}\text { Bank of } \\
\text { Novascotia }\end{array}$ \\
\hline State Street & $\begin{array}{l}\text { Bank of } \\
\text { Novascotia }\end{array}$ & $\begin{array}{l}\text { Bank of } \\
\text { Novascotia }\end{array}$ & $\begin{array}{l}\text { Bank of NY } \\
\text { Mellon (BNY } \\
\text { Mellon) }\end{array}$ & $\begin{array}{l}\text { Bank of NY } \\
\text { Mellon (BNY } \\
\text { Mellon) }\end{array}$ & $\begin{array}{l}\text { Bank of NY } \\
\text { Mellon (BNY } \\
\text { Mellon) }\end{array}$ & $\begin{array}{l}\text { Bank of NY } \\
\text { Mellon (BNY } \\
\text { Mellon) }\end{array}$ \\
\hline $\begin{array}{l}\text { Bank of } \\
\text { Novascotia }\end{array}$ & $\begin{array}{l}\text { Bank of NY } \\
\text { Mellon (BNY } \\
\text { Mellon) }\end{array}$ & $\begin{array}{l}\text { Bank of NY } \\
\text { Mellon (BNY } \\
\text { Mellon) }\end{array}$ & $\begin{array}{l}\text { Mizuho } \\
\text { Corporate Bank }\end{array}$ & $\begin{array}{l}\text { Mizuho } \\
\text { Corporate Bank }\end{array}$ & $\begin{array}{l}\text { Mizuho } \\
\text { Corporate Bank }\end{array}$ & $\begin{array}{l}\text { Mizuho } \\
\text { Corporate Bank }\end{array}$ \\
\hline $\begin{array}{l}\text { Bank of NY } \\
\text { Mellon (BNY } \\
\text { Mellon) }\end{array}$ & $\begin{array}{l}\text { Mizuho } \\
\text { Corporate Bank }\end{array}$ & $\begin{array}{l}\text { Mizuho } \\
\text { Corporate Bank }\end{array}$ & $\begin{array}{l}\text { United Overseas } \\
\text { Bank }\end{array}$ & $\begin{array}{l}\text { United Overseas } \\
\text { Bank }\end{array}$ & $\begin{array}{l}\text { United Overseas } \\
\text { Bank }\end{array}$ & $\begin{array}{l}\text { United Overseas } \\
\text { Bank }\end{array}$ \\
\hline $\begin{array}{l}\text { Mizuho } \\
\text { Corporate Bank }\end{array}$ & $\begin{array}{l}\text { United Overseas } \\
\text { Bank }\end{array}$ & $\begin{array}{l}\text { United Overseas } \\
\text { Bank }\end{array}$ & Deutsche Bank & Deutsche Bank & Deutsche Bank & Deutsche Bank \\
\hline $\begin{array}{l}\text { United Overseas } \\
\text { Bank }\end{array}$ & Deutsche Bank & Deutsche Bank & $\begin{array}{l}\text { Bank of } \\
\text { Tokyo-Mitsubishi } \\
\text { UFJ }\end{array}$ & $\begin{array}{l}\text { Bank of } \\
\text { Tokyo-Mitsubishi } \\
\text { UFJ }\end{array}$ & $\begin{array}{l}\text { Bank of } \\
\text { Tokyo-Mitsubishi } \\
\text { UFJ }\end{array}$ & $\begin{array}{l}\text { Bank of } \\
\text { Tokyo-Mitsubishi } \\
\text { UFJ }\end{array}$ \\
\hline Deutsche Bank & $\begin{array}{l}\text { Bank of } \\
\text { Tokyo-Mitsubishi } \\
\text { UFJ }\end{array}$ & $\begin{array}{l}\text { Bank of } \\
\text { Tokyo-Mitsubishi } \\
\text { UFJ }\end{array}$ & Metrobank & Metrobank & Metrobank & Metrobank \\
\hline $\begin{array}{l}\text { Bank of } \\
\text { Tokyo-Mitsubishi } \\
\text { UFJ }\end{array}$ & Metrobank & Metrobank & Bank Mellat & Bank Mellat & Bank Mellat & Bank Mellat \\
\hline Metrobank & Bank Mellat & Bank Mellat & $\begin{array}{l}\text { Sumitomo Mitsui } \\
\text { Bank Ltd. }\end{array}$ & $\begin{array}{l}\text { Sumitomo Mitsui } \\
\text { Bank Ltd. }\end{array}$ & $\begin{array}{l}\text { Sumitomo Mitsui } \\
\text { Bank Ltd. }\end{array}$ & $\begin{array}{l}\text { Sumitomo Mitsui } \\
\text { Bank Ltd. }\end{array}$ \\
\hline Bank Mellat & $\begin{array}{l}\text { Sumitomo Mitsui } \\
\text { Bank Ltd. }\end{array}$ & $\begin{array}{l}\text { Sumitomo Mitsui } \\
\text { Bank Ltd. }\end{array}$ & Barclays & Barclays & Barclays & Barclays \\
\hline
\end{tabular}




\begin{tabular}{|c|c|c|c|c|c|c|}
\hline 2006 & 2007 & 2008 & 2009 & 2010 & 2011 & 2012 \\
\hline $\begin{array}{l}\text { Sumitomo Mitsui } \\
\text { Bank Ltd. }\end{array}$ & Barclays & Barclays & $\begin{array}{l}\text { Bank of America } \\
\text { Corporation }\end{array}$ & $\begin{array}{l}\text { Bank of America } \\
\text { Corporation }\end{array}$ & $\begin{array}{l}\text { Bank of America } \\
\text { Corporation }\end{array}$ & $\begin{array}{l}\text { Bank of America } \\
\text { Corporation }\end{array}$ \\
\hline Barclays & $\begin{array}{l}\text { Bank of America } \\
\text { Corporation }\end{array}$ & $\begin{array}{l}\text { Bank of America } \\
\text { Corporation }\end{array}$ & Yamaguchi Bank & Yamaguchi Bank & Yamaguchi Bank & Yamaguchi Bank \\
\hline $\begin{array}{l}\text { Bank of America } \\
\text { Corporation }\end{array}$ & Yamaguchi Bank & Yamaguchi Bank & RBS & RBS & RBS & RBS \\
\hline Yamaguchi Bank & RBS & RBS & $\begin{array}{l}\text { Indian Overseas } \\
\text { Bank }\end{array}$ & $\begin{array}{l}\text { Indian Overseas } \\
\text { Bank }\end{array}$ & $\begin{array}{l}\text { Indian Overseas } \\
\text { Bank }\end{array}$ & $\begin{array}{l}\text { Indian Overseas } \\
\text { Bank }\end{array}$ \\
\hline RBS & $\begin{array}{l}\text { Indian Overseas } \\
\text { Bank }\end{array}$ & $\begin{array}{l}\text { Indian Overseas } \\
\text { Bank }\end{array}$ & $\begin{array}{l}\text { Industrial and } \\
\text { Commercial } \\
\text { Bank of China } \\
\text { Limited }\end{array}$ & $\begin{array}{l}\text { Industrial and } \\
\text { Commercial } \\
\text { Bank of China } \\
\text { Limited }\end{array}$ & $\begin{array}{l}\text { Industrial and } \\
\text { Commercial } \\
\text { Bank of China } \\
\text { Limited }\end{array}$ & $\begin{array}{l}\text { Industrial and } \\
\text { Commercial } \\
\text { Bank of China } \\
\text { Limited }\end{array}$ \\
\hline $\begin{array}{l}\text { Indian Overseas } \\
\text { Bank }\end{array}$ & $\begin{array}{l}\text { Industrial and } \\
\text { Commercial } \\
\text { Bank of China } \\
\text { Limited }\end{array}$ & $\begin{array}{l}\text { Industrial and } \\
\text { Commercial } \\
\text { Bank of China } \\
\text { Limited }\end{array}$ & $\begin{array}{l}\text { China } \\
\text { Construction } \\
\text { Bank }\end{array}$ & $\begin{array}{l}\text { China } \\
\text { Construction } \\
\text { Bank }\end{array}$ & $\begin{array}{l}\text { China } \\
\text { Construction } \\
\text { Bank }\end{array}$ & $\begin{array}{l}\text { China } \\
\text { Construction } \\
\text { Bank }\end{array}$ \\
\hline $\begin{array}{l}\text { Industrial and } \\
\text { Commercial } \\
\text { Bank of China } \\
\text { Limited }\end{array}$ & $\begin{array}{l}\text { China } \\
\text { Construction } \\
\text { Bank }\end{array}$ & $\begin{array}{l}\text { China } \\
\text { Construction } \\
\text { Bank }\end{array}$ & $\begin{array}{l}\text { J.P. Morgan } \\
\text { Chase and } \\
\text { Corporation }\end{array}$ & $\begin{array}{l}\text { J.P. Morgan } \\
\text { Chase and } \\
\text { Corporation }\end{array}$ & $\begin{array}{l}\text { J.P. Morgan } \\
\text { Chase and } \\
\text { Corporation }\end{array}$ & $\begin{array}{l}\text { J.P. Morgan } \\
\text { Chase and } \\
\text { Corporation }\end{array}$ \\
\hline $\begin{array}{l}\text { China } \\
\text { Construction } \\
\text { Bank }\end{array}$ & $\begin{array}{l}\text { J.P. Morgan } \\
\text { Chase and } \\
\text { Corporation }\end{array}$ & $\begin{array}{l}\text { J.P. Morgan } \\
\text { Chase and } \\
\text { Corporation }\end{array}$ & $\begin{array}{l}\text { National Bank of } \\
\text { Pakistan }\end{array}$ & $\begin{array}{l}\text { National Bank of } \\
\text { Pakistan }\end{array}$ & $\begin{array}{l}\text { National Bank of } \\
\text { Pakistan }\end{array}$ & $\begin{array}{l}\text { National Bank of } \\
\text { Pakistan }\end{array}$ \\
\hline $\begin{array}{l}\text { J.P. Morgan } \\
\text { Chase and } \\
\text { Corporation }\end{array}$ & $\begin{array}{l}\text { National Bank of } \\
\text { Pakistan }\end{array}$ & $\begin{array}{l}\text { National Bank of } \\
\text { Pakistan }\end{array}$ & Wells Fargo & Wells Fargo & Wells Fargo & Wells Fargo \\
\hline $\begin{array}{l}\text { National Bank of } \\
\text { Pakistan }\end{array}$ & Wells Fargo & Wells Fargo & HSBC & HSBC & $\mathrm{HSBC}$ & HSBC \\
\hline Wells Fargo & HSBC & HSBC & UBS Bank & UBS Bank & UBS Bank & UBS Bank \\
\hline HSBC & UBS Bank & UBS Bank & $\begin{array}{l}\text { Bank Of } \\
\text { Communications }\end{array}$ & $\begin{array}{l}\text { Bank Of } \\
\text { Communications }\end{array}$ & $\begin{array}{l}\text { Bank Of } \\
\text { Communications }\end{array}$ & $\begin{array}{l}\text { Bank Of } \\
\text { Communications }\end{array}$ \\
\hline UBS Bank & $\begin{array}{l}\text { Bank Of } \\
\text { Communications }\end{array}$ & $\begin{array}{l}\text { Bank Of } \\
\text { Communications }\end{array}$ & Morgan Stanley & Morgan Stanley & Morgan Stanley & Morgan Stanley \\
\hline $\begin{array}{l}\text { Bank Of } \\
\text { Communications }\end{array}$ & Morgan Stanley & Morgan Stanley & Goldman Sachs & Goldman Sachs & Goldman Sachs & Goldman Sachs \\
\hline Morgan Stanley & Goldman Sachs & Goldman Sachs & $\begin{array}{l}\text { Merrill Lynch } \\
\text { International } \\
\text { Bank Limited }\end{array}$ & $\begin{array}{l}\text { Landesbank } \\
\text { Baden- } \\
\text { Wurttemberg }\end{array}$ & $\begin{array}{l}\text { Landesbank } \\
\text { Baden- } \\
\text { Wurttemberg }\end{array}$ & $\begin{array}{l}\text { Landesbank } \\
\text { Baden- } \\
\text { Wurttemberg }\end{array}$ \\
\hline \multirow[t]{3}{*}{ Goldman Sachs } & & $\begin{array}{l}\text { Merrill Lynch } \\
\text { International } \\
\text { Bank Limited }\end{array}$ & $\begin{array}{l}\text { Landesbank } \\
\text { Baden- } \\
\text { Wurttemberg }\end{array}$ & Macquarie Bank & Macquarie Bank & Macquarie Bank \\
\hline & & $\begin{array}{l}\text { Lehman Brothers } \\
\text { Bankhaus }\end{array}$ & Macquarie Bank & & $\begin{array}{l}\text { Banco Bilbao } \\
\text { Vizcaya } \\
\text { Argentaria }\end{array}$ & $\begin{array}{l}\text { Banco Bilbao } \\
\text { Vizcaya } \\
\text { Argentaria }\end{array}$ \\
\hline & & $\begin{array}{l}\text { Landesbank } \\
\text { Baden- } \\
\text { Wurttemberg }\end{array}$ & & & & $\begin{array}{l}\text { Agricultural } \\
\text { Bank of China }\end{array}$ \\
\hline 37 & 36 & 39 & 38 & 37 & 38 & 39 \\
\hline
\end{tabular}


(d) Foreign Bank Subsidiaries, 2000-2012

\begin{tabular}{|c|c|c|c|c|c|c|c|c|c|}
\hline 2000 & \multicolumn{2}{|l|}{2001} & \multicolumn{2}{|c|}{2002} & \multicolumn{2}{|c|}{2003} & \multicolumn{2}{|r|}{2004} & 2005 \\
\hline $\begin{array}{l}\text { Standard Chartered } \\
\text { Bank Korea Limited }\end{array}$ & \multicolumn{2}{|c|}{$\begin{array}{l}\text { Standard Chartered } \\
\text { Bank Korea Limited }\end{array}$} & \multicolumn{2}{|c|}{$\begin{array}{l}\text { Standard Chartered } \\
\text { Bank Korea Limited }\end{array}$} & \multicolumn{2}{|c|}{$\begin{array}{l}\text { Standard Chartered } \\
\text { Bank Korea Limited }\end{array}$} & \multicolumn{2}{|c|}{$\begin{array}{l}\text { Standard Chartered } \\
\text { Bank Korea Limited }\end{array}$} & $\begin{array}{l}\text { Standard Chartered } \\
\text { Bank Korea Limited }\end{array}$ \\
\hline \multirow[t]{2}{*}{ Citi bank Korea } & \multicolumn{2}{|c|}{ Citi bank Korea } & \multicolumn{2}{|c|}{ Citi bank Korea } & \multicolumn{2}{|c|}{ Citi bank Korea } & \multicolumn{2}{|c|}{ Citi bank Korea } & Citi bank Korea \\
\hline & & & & & $\begin{array}{l}\text { Korea E } \\
\text { Bank }\end{array}$ & xchange & $\begin{array}{l}\text { Korea } \\
\text { Bank }\end{array}$ & Exchange & $\begin{array}{l}\text { Korea Exchange } \\
\text { Bank }\end{array}$ \\
\hline 2 & \multicolumn{2}{|l|}{2} & \multicolumn{2}{|l|}{2} & \multicolumn{2}{|r|}{3} & \multicolumn{2}{|r|}{3} & 3 \\
\hline 2006 & 2007 & & 2008 & \multicolumn{2}{|c|}{2009} & \multicolumn{2}{|l|}{2010} & 2011 & 2012 \\
\hline $\begin{array}{l}\text { Standard } \\
\text { Chartered Bank } \\
\text { Korea Limited }\end{array}$ & $\begin{array}{l}\text { Standard } \\
\text { Chartered Bank } \\
\text { Korea Limited }\end{array}$ & \multicolumn{2}{|c|}{$\begin{array}{l}\text { Standard } \\
\text { Chartered Bank } \\
\text { Korea Limited }\end{array}$} & \multicolumn{2}{|c|}{$\begin{array}{l}\text { Standard } \\
\text { Chartered Bank } \\
\text { Korea Limited }\end{array}$} & \multicolumn{2}{|c|}{$\begin{array}{l}\text { Standard } \\
\text { Chartered Bank } \\
\text { Korea Limited }\end{array}$} & $\begin{array}{l}\text { Standard } \\
\text { Chartered Bank } \\
\text { Korea Limited }\end{array}$ & $\begin{array}{l}\text { Standard } \\
\text { Chartered Bank } \\
\text { Korea Limited }\end{array}$ \\
\hline Citi bank Korea & Citi bank Korea & \multicolumn{2}{|c|}{ Citi bank Korea } & \multicolumn{2}{|c|}{ Citi bank Korea } & \multicolumn{2}{|c|}{ Citi bank Korea } & Citi bank Korea & Citi bank Korea \\
\hline $\begin{array}{l}\text { Korea Exchange } \\
\text { Bank }\end{array}$ & $\begin{array}{l}\text { Korea Exchange } \\
\text { Bank }\end{array}$ & \multicolumn{2}{|c|}{$\begin{array}{l}\text { Korea Exchange } \\
\text { Bank }\end{array}$} & \multicolumn{2}{|c|}{$\begin{array}{l}\text { Korea Exchange } \\
\text { Bank }\end{array}$} & \multicolumn{2}{|c|}{$\begin{array}{l}\text { Korea Exchange } \\
\text { Bank }\end{array}$} & $\begin{array}{l}\text { Korea Exchange } \\
\text { Bank }\end{array}$ & \\
\hline 3 & 3 & & 3 & 3 & & 3 & & 3 & 2 \\
\hline
\end{tabular}

(e) Total Number of Banks, 2000-2012

\begin{tabular}{c|c|c|c|c|c|c}
\hline 2000 & 2001 & \multicolumn{2}{|c|}{2002} & 2003 & 2004 & 2005 \\
\hline 62 & 63 & \multicolumn{2}{|c|}{58} & 54 & 54 & 53 \\
\hline 2006 & 2007 & 2008 & 2009 & 2010 & 2011 & 2012 \\
\hline 52 & 49 & 52 & 51 & 50 & 51 & 52 \\
\hline
\end{tabular}




\section{<Abstract in Korean>}

\section{전방남*, 임호성**, Ji Wu***}

본고는 외국은행(외은지점 및 외국인 소유 국내은행)이 통화정책 파급경로에 미치는 영향을 패널자료를 이용하여 분석하였다. 분석결과 외국은행은 평상 시에는 통화정책의 신용경로, 즉 기준금리인하가 대출률 상승으로 이어지는 데 기여하였으나, 위기 시에는 기준금리인하에도 불구하고 대출을 오히려 줄이는 등 신용경로를 저해하는 행태를 보이는 것으로 나타났다.

이러한 결과는 외국은행의 경우 본점과의 자금거래, 즉 내부자금조달시장에 대한 접근이 가능함에 따라 주재국의 자금사정보다는 본점의 자금사정에 보다 의존하기 때문인 것으로 판단된다. 따라서 이는 통화정책과 금융감독정책을 수행함에 있어 위기 시 외국은행의 행태가 달라질 수 있다는 점을 고려하여야 할 필요가 있음을 시사한다.

* Drexel University 경제학과 교수

** 한국은행 경제연구원 전문연구원

*** Pennsylvania State University - Harrisburg 경제학과 및 중국 Southwestern University of Finance and Economics 교수 